\title{
CONCRETE COMPOSITE SLAB CONSTRUCTION: STATE OF THE
}

\author{
ART \\ A.Siva ${ }^{1}$, Thamilselvi $\mathbf{P}^{2}$, Saddam M Ahmed ${ }^{3}$, Senthil $\mathbf{R}^{4}$ \\ ${ }^{1}$ Research Scholar, Department of Civil Engineering, Anna University, Chennai, India \\ ${ }^{2}$ Professor, Division of Structural Engineering, Department of Civil Engineering, Anna University, Chennai, India \\ ${ }^{3}$ Assistant Professor, Department of Civil Engineering, Mosul University, IRAQ \\ ${ }^{4}$ Professor, Division of Structural Engineering, Department of Civil Engineering, Anna University, Chennai, India
}

\begin{abstract}
In the recent trends emerging day by day in the construction industry, composite construction method has gained its popularity for its economical usage of materials and providing higher sustainability than conventional concrete construction system. Several factors that affect the degree of slippage deterioration in composite slab, e.g. embossments, shape of profiled sheeting and shear connector types. The common types of failure modes in composite slabs are flexural failure, shear failure and combination of flexural-shear failure mechanism. Small scale test helps to determine the shear resistance capacity, slip and shear action between the corrugated steel and harden concrete. Small scale tests usually used Push out, Pull out, Pull over or elemental bending tests. The reduction in the size of the structural components, thereby decreasing the dead loads which results in the construction of more floors (i.e.) increasing the service living area. The shear action between the sheet and the concrete can be achieved by providing frictional interlock (shape of the profiled sheeting), mechanical interlock (embossments on the sheet) and end anchorage interlock (studs on the profiled sheeting). The advantages of composite construction over steel reinforced concrete construction are reducing the thickness of the floor slab with a simultaneous proving in the load bearing capacity of the slab. This paper also discusses an attempts on quantifying the slippage in terms of $m$ - $k$ method. Finally, the areas that need further research are highlighted and the need for incorporating composite slab contribution into building design guidelines is emphasized.
\end{abstract}

Keywords: Composite Slab, Shear Failure, Slip and Deflection

\section{INTRODUCTION}

Composite construction method is a widely used diaphragm strengthening method where two different materials performing a composite action. The composite action of the composite slab depends upon shear action between the corrugated steel sheeting on the hardened concrete. The shear action between the sheet and the concrete can be achieved by providing frictional interlock (shape of the profiled sheeting), mechanical interlock (embossments on the sheet) and end anchorage interlock (studs on the profiled sheeting). Depending upon the transfer of shear stress various types of profiled sheeting such as rectangular trapezoidal and dovetail re-entrant profiled sheeting are generally selected. In recent years the composite slabs have gained popularity in various residential, commercial, industrial and institutional constructions. The advantages of composite construction over steel reinforced concrete construction are reducing the thickness of the floor slab with a simultaneous proving in the load bearing capacity of the slab. Decreasing the indirect cost involved in construction due to which faster construction or installation progress. The reduction in the size of the structural components, thereby decreasing the dead loads which results in the construction of more floors (i.e.) increasing the service living area. The steel decking itself act as an external reinforcement and eliminate the need for formworks. Figure1, 2 and 3 represents the different type of embossment and different profile geometry.

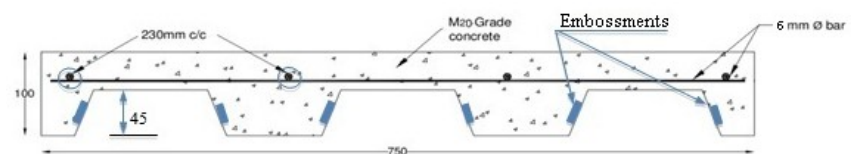

Fig 1. Trapezoidal profile with embossments
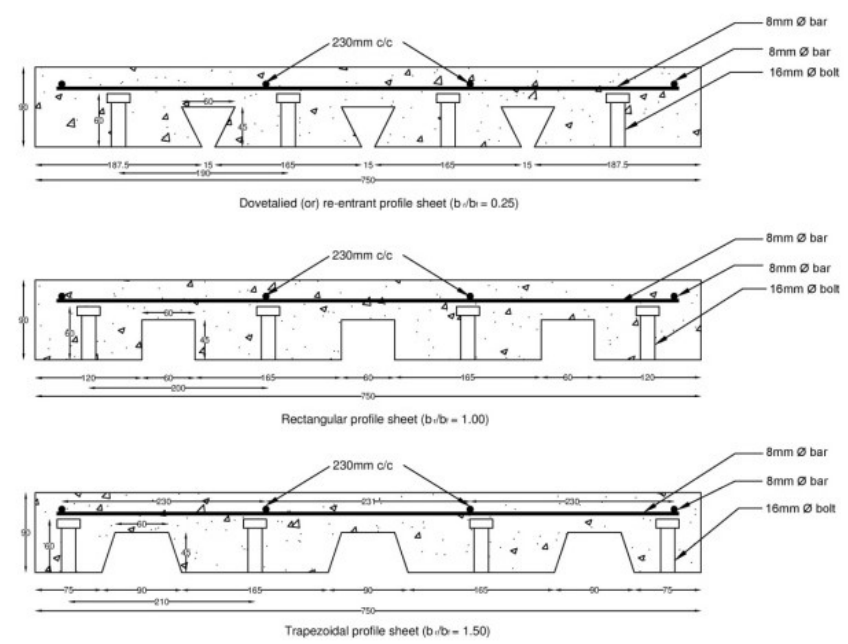

Fig 2. Different profile geometry with stud shear connector 


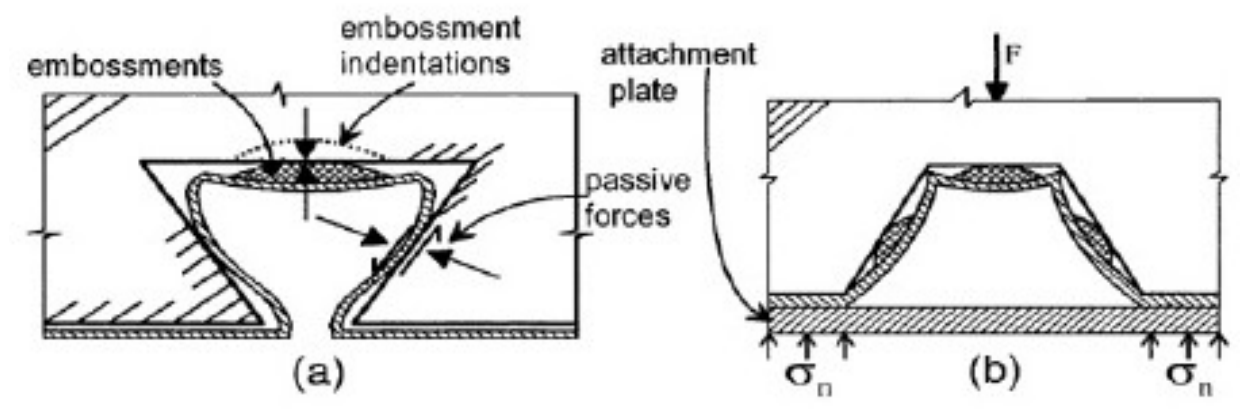

Fig 3. Type of punching (Embossment or Indentation)

\section{TEST ON COMPOSITE SLABS}

To determine the parameters governing the behaviour of the composite slab small scale and full scale tests are carried out, in the last three decades. Small scale test helps to determine the shear resistance capacity, slip and shear action between the corrugated steel and harden concrete. Small scale tests usually used Push out, Pull out, Pull over or elemental bending tests. The slip, curvature slip and the longitudinal shear capacity are determined by small scale tests. On the other hand, full scale tests are focused on the flexural strength, deflection and the delamination of profiled steel sheeting. Euro Code 4 recommends two testing methods to determine the behaviour of composite slab. As per Euro Code 4 standards, the slab is considered to be ductile, if the maximum load is 10 percent greater than that of the loads causing $0.5 \mathrm{~mm}$ end slip. Based on the results of the full scale tests the slabs are marked as ductile or brittle. The common types of failure modes in composite slabs are flexural failure, shear failure and combination of flexural-shear failure mechanism.

\subsection{Flexure Failure Mode}

The flexural failure depends upon the shear span. The shear span is the distance between the point of application of the load and the nearest support. The composite slab with longer shear spans is prone to fail easily by flexural failure.

\subsection{Shear Failure Mode}

The shear failure is characterized by the sliding of the hardened concrete over the steel sheeting, when the load is increased. As the load is increased, the diagonal cracks are formed adjacent or below the applied load. When the load reaches its threshold, shear bond failure occurs.

\subsection{Combination of Flexural-Shear Failure Mode}

The shear failure is characterized by the sliding of the hardened concrete over the steel sheeting with the flexural failure at the same time, Figure 4 different type of failure in composite deck slabs.

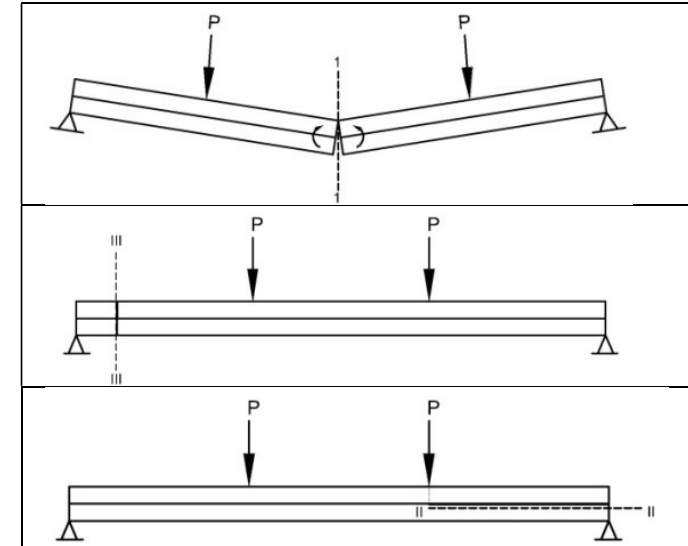

Fig 4. Different type of failure in composite deck slabs

\section{LOADING SCHEME}

\subsection{Static Loading}

In static loading, the concentrated load is applied over the composite slab. The deflection is measured simultaneously as the load is progressively increased; the load is applied until the specimen fails. Thus, the load-deflection behaviour and the end-slip behaviour are measured. The loaddeflection behaviour is the relationship between the loading and the deflection which results in the formation and propagation of cracks from the bottom of the slab to the point of application of load. The end-slip is stated as the horizontal movement of concrete over the steel. When there is a progressive application of load, end-slip occurs followed by the delamination of composite slab.

\subsection{Cyclic Loading}

In cyclic loading, the load is applied in a cyclic pattern over the composite slab. The main advantage in this type of loading is the energy absorbed or dissipated per cycle load which can be measured.

Table.1 summarizes the researches which were carried out by various authors and main outcome results.

\section{CONCLUSION}

In this paper, an attempt on quantify the performance of composite concrete floor slabs in steel framed which made by various researchers are discussed and highlighted. However, the area needs further studies to better understanding the complex behaviour of composite 
concrete slab under both static and dynamic loading. An asses for exact composite slab behaviour can contribute for the industry and enhancing the growth of development.

\section{ACKNOWLEDGEMENT}

The authors are grateful to the Structural Engineering Laboratory, Division of Structural Engineering, Anna University, Chennai for their partial support of this work.

\section{REFERENCES}

[1] ML Porter and CE Ekberg, Design Vs Test results for steel deck floor slab, 3rd international SpecialityConfrence on cold-formed steel structures, St Louis, Missouri, USA, 1975.

[2] KCG Ong and MA Mansurt, Shear bond capacity of composite slabs made with profiled sheeting, The international Journal of cement composites and Light weight concrete, 8: pp. 231-237, 1986.

[3] LD Lutterell, Methods for predicting strength in composite slab, 18th International speciality on cold form steel structures, St Louis, Missousi, USA: pp. 11$12,1986$.

[4] HD Wright, HR Evans and PW Harding, The use of profiled steel sheeting in floor construction, Journal of constructional steel research, 7: pp. 279-295, 1987.

[5] HD Writes and HR Erans, A folded plate method of analysis for profiled steel sheeting in composite floor construction, Thin Walled Structures, 5: pp 21-37, 1987.

[6] H.D Wright, A plate model for composite slab analysis, Thin Walled Structures, 10: pp. 299-318, 1990.

[7] JWB Stark and JWPM Brekelmans, Plastic design of continuous composite slabs, Journal of Constructional steel Research, 15: pp. 23-47, 1990.

[8] KW Poh and MM Atlard, Calculating the load deflection behaviour of simply supported composite slabs with slip interface, Engineering Structures, Vol no:15, pp. 359-367,1992.

[9] BJ Daniels and M Crisinel, Composite slab behaviour and strength analysis Part 1:Calculation procedure, Journal of Structural Engineering, 119: pp. 16-35, 1993.

[10] SA Andrade, PCGS Vellasco, JGS Silva and TH Takey, Standardized composite slab system for building constructions, Journal of Constructional Steel Research, 60: pp. 493-524, 2004.

[11] R Abdullah and WS Easterling, Elemental bending test and modelling of shear bond in composite slabs, Jouornal of Structural Engineering, 113(9): pp. 12681277, 2004.

[12] D Lams and J Qureshi, Prediction of longitudinal shear resistance of composite slabs with profile sheeting to Eurocode 4, The regency steel Asia International Symposium on Innovations in Structural Steel, RSAISISS 2008, Singapore.
[13] YJ Jeong, HY Kim and HB Koo, Longitudinal shear resistance of steel concrete composite slabs with perfobond shear connectors, Journal of Constructional Steel Research, 65: pp.81-88, 2009.

[14] JM Irwan, AH Hanzal and I Azmi, Test of shear transfer enhancement in symmetric cold formed steel concrete composite beam, Journal of constructional steel research, 65: pp. 2087-2098, 2009.

[15] S Chen, X Shi and Z Qui, Shear bond failure in composite slab a detailed experimental study, Steel and Composite Structures, 11: pp. 233-250, 2011.

[16] A Bouchair, J Bujnak, P Duratna and A Lachal, Modelling of the steel concrete push-out test, Procedia Engineering, 40: pp. 102-107, 2012.

[17] TAC Pires, JPC Rodrigues JJR Silva, Fire resistance of concrete filled circular hollow columns with resistance thermal elongation, Journal of Constructional Steel Research, 77: pp. 82-94, 2013.

[18] RI Gilbert, Time dependent stiffness of cracked reinforced and composite concrete slab, Procedia Engineering, 57: pp. 19-34, 2013.

[19] KN Lakshmikandhan, P Sivakumar, R Ravichandran and SA Jayachandral, Investigation on efficiently interfaced steel concrete composite deck slabs, Journal of Structures, $10:$ pp 22-31, 2013.

[20] A Abdullah, CG Bailey, ZJ Wu, Test investigation the punching shear of a column- slab connection strengthened with non-prestressed (or) prestressed FRP plates, Construction and Building Materials, 48: pp. 1134-1144, 2013.

[21] A.Gholamhosini, R.I Gilbert, M.A Bradford, Z.T Ching, Longitudinal shear stress and bond slip relationship on composite concrete slab, Engineering structural and bond slip relationship in composite concrete slab, Vol no 69, pp. 37-48, 2014.

[22] A. Siva, R. Senthil and Saddam M Ahmed, Experimental investigation on longitudinal shear behaviour of steel concrete composite deck slab, Journal of Structural Engineering, Vol. 43, No. 5, December 2016 - January 2017 pp. 445-453.

[23] S. Swaminathan1, A. Siva, R. Senthil and Kinson Prabu, Experimental Investigation on Shear Connectors in Steel-concrete Composite Deck Slabs, Indian Journal of Science and Technology, Vol. 9(30), DOI: 10.17485/ijst/2016/v9i30/96291, August 2016.

[24] A.Siva, S.Swaminathan, K.Prasanth and R.Senthil, Experimental Investigation of Trapezoidal Profile Sheeting Under Varying Shear Spans, Applied Mechanics and Materials, Vol. 845, pp 148-153.

[25] A.Siva, R.Senthil and S.Swaminathan, Assessment of longitudinal shear strength of Composite deck slab, International Journal of Innovation and Scientific Research, Vol. 24 No. 2 Jun. 2016, pp. 277-284. 


\section{BIOGRAPHIES}

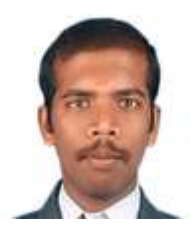

Research Scholar, Division of Structural Engineering, Department of Civil Engineering, Anna University, Chennai, India.

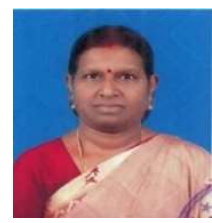

Associate Professor, Division of Structural Engineering, Department of Civil Engineering, Anna University, Chennai, India.

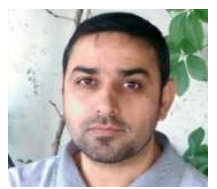

Assistant Professor, Department of Civil Engineering, Mosul University, IRAQ.

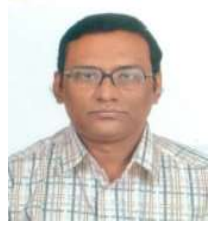

Professor, Division of Structural Engineering, Department of Civil Engineering, Anna University, Chennai, India

Table: 1 Experimental investigation by various authors for the composite slab elements.

\begin{tabular}{|c|c|c|c|c|c|c|c|c|c|}
\hline $\begin{array}{l}\text { S } \\
. I\end{array}$ & Author & $\begin{array}{l}\text { Countr } \\
\text { y }\end{array}$ & Year & $\begin{array}{l}\text { Shape of } \\
\text { the section }\end{array}$ & $\begin{array}{l}\text { Type of } \\
\text { loading }\end{array}$ & $\begin{array}{l}* \\
\mathbf{A} / \\
\mathbf{E} / \\
\mathbf{N}\end{array}$ & $\begin{array}{l}\text { Numbe } \\
\mathbf{r} \text { of } \\
\text { tests } \\
\text { specime } \\
\text { n }\end{array}$ & Variable study & Remarks \\
\hline 1 & $\begin{array}{l}\text { Porter and } \\
\text { Eleberg }\end{array}$ & USA & 1975 & Rectangular & $\begin{array}{l}\text { Static } \\
\text { and } \\
\text { cyclic } \\
\text { loading }\end{array}$ & $\begin{array}{l}\mathrm{A} \\
\& \\
\mathrm{E}\end{array}$ & $\begin{array}{l}353 \\
\text { samples }\end{array}$ & $\begin{array}{l}\text { i) The shear bond } \\
\text { End slip behaviour } \\
\text { was used in this } \\
\text { journal. } \\
\text { ii) predicting the } \\
\text { maximum load for } \\
\text { shear bond by using } \\
\text { the linear regression } \\
\text { relationship }\end{array}$ & $\begin{array}{l}\text { For simple span slab } \\
\text { element the test gives } \\
\text { linear regression } \\
\text { relationship and the } \\
\text { load deflection data. } \\
\text { Recommendation } \\
\text { design equations for } \\
\text { shear-bond which } \\
\text { provide a consistent } \\
\text { margin of safety is } \\
\text { suggested }\end{array}$ \\
\hline 2 & $\begin{array}{l}\text { Ong and } \\
\text { Mansurt }\end{array}$ & $\begin{array}{l}\text { Singap } \\
\text { ore }\end{array}$ & 1986 & Rectangular & $\begin{array}{l}\text { Static } \\
\text { and live } \\
\text { loading }\end{array}$ & $\mathrm{E}$ & $\begin{array}{l}10 \\
\text { samples }\end{array}$ & $\begin{array}{l}\text { The regression } \\
\text { analysis for the slab } \\
\text { is done by shear } \\
\text { tests }\end{array}$ & $\begin{array}{l}\text { i) Two linear } \\
\text { regression plots was } \\
\text { obtained } \\
\text { ii) The slabs without } \\
\text { shear devices tends to } \\
\text { fail in shear bond } \\
\text { mode under third point } \\
\text { load location. }\end{array}$ \\
\hline 3 & Lutterll & USA & 1986 & Trapezoidal & $\begin{array}{l}\text { Static } \\
\text { loading }\end{array}$ & A & $\begin{array}{l}\text { Over } 75 \\
\text { samples }\end{array}$ & $\begin{array}{l}\text { Three types of slip } \\
\text { resistances were } \\
\text { adopted } \\
\text { i) Adhesive bond } \\
\text { ii) Mechanical bond } \\
\text { from embossments, } \\
\text { and } \\
\text { iii) Shear connectors }\end{array}$ & $\begin{array}{l}\text { The two broad } \\
\text { categories of deck } \\
\text { types were identified } \\
\text { by providing } \\
\text { embossments in a } \\
\text { vertical manner in the } \\
\text { web and lugs running } \\
\text { horizontally. Then } \\
\text { formulae were derived } \\
\text { to describe the flexural } \\
\text { strength of the slab. }\end{array}$ \\
\hline 4 & $\begin{array}{l}\text { Wright, } \\
\text { Harding } \\
\text { and Evans }\end{array}$ & UK & 1987 & $\begin{array}{l}\text { Rectangular } \\
\& \\
\text { trapezoidal } \\
\text { profiles }\end{array}$ & $\begin{array}{l}\text { Static } \\
\text { loading }\end{array}$ & $\begin{array}{l}E \\
\& \\
N\end{array}$ & $\begin{array}{l}40 \\
\text { samples }\end{array}$ & $\begin{array}{l}\text { Determination the } \\
\text { load deflection } \\
\text { characteristics }\end{array}$ & $\begin{array}{l}\text { There is a need for an } \\
\text { efficient structural } \\
\text { design for the slabs } \\
\text { where economy plays } \\
\text { a major role. }\end{array}$ \\
\hline
\end{tabular}




\begin{tabular}{|c|c|c|c|c|c|c|c|c|c|}
\hline 5 & $\begin{array}{l}\text { Wright and } \\
\text { Evans }\end{array}$ & UK & 1987 & Trapezoidal & $\begin{array}{l}\text { Static } \\
\text { loading }\end{array}$ & $\begin{array}{l}\text { A } \\
\& \\
\text { N }\end{array}$ & $\begin{array}{l}\text { Over } \\
200 \\
\text { samples }\end{array}$ & $\begin{array}{l}\text { i)Lapped joints and } \\
\text { crimped joints were } \\
\text { provided. } \\
\text { ii) Analysis were } \\
\text { made by fold plate } \\
\text { analysis, and } \\
\text { iii) The effective } \\
\text { thickness for the } \\
\text { composite element } \\
\text { was derived. }\end{array}$ & $\begin{array}{l}\text { Accurate and versatile } \\
\text { results were obtained } \\
\text { using fold plate } \\
\text { analysis. }\end{array}$ \\
\hline 6 & Wright & UK & 1990 & Trapezoidal & $\begin{array}{l}\text { Dynami } \\
\text { c } \\
\text { loading }\end{array}$ & $\begin{array}{l}\text { A } \\
\& \\
\text { E }\end{array}$ & $\begin{array}{l}3 \\
\text { samples }\end{array}$ & $\begin{array}{l}\text { i)Welding } \\
\text { reinforcement bars } \\
\text { with the sheets. } \\
\text { ii) Dummy shear } \\
\text { elements connecting } \\
\text { the steel plates and } \\
\text { concrete plates. }\end{array}$ & $\begin{array}{l}\text { i) Analysis by folded } \\
\text { plate method found to } \\
\text { be useful, } \\
\text { ii) Horizontal plates } \\
\text { take major } \\
\text { longitudinal forces } \\
\text { due to bending, and } \\
\text { iii) In composite slab } \\
\text { behaviour } \\
\text { presence of slip } \\
\text { between the two } \\
\text { materials causes non- } \\
\text { linear behaviour }\end{array}$ \\
\hline 7 & $\begin{array}{l}\text { Stark and } \\
\text { Brekelman } \\
\mathrm{s}\end{array}$ & $\begin{array}{l}\text { Netherl } \\
\text { and }\end{array}$ & 1990 & Trapezoidal & $\begin{array}{l}\text { Static } \\
\text { and } \\
\text { cyclic } \\
\text { loading }\end{array}$ & $\begin{array}{l}\text { E } \\
\& \\
N\end{array}$ & $\begin{array}{l}8 \\
\text { samples }\end{array}$ & $\begin{array}{l}\text { i) Plastic analysis on } \\
\text { the composite slab, } \\
\text { ii) A simplified } \\
\text { calculation method } \\
\text { is adopted for the } \\
\text { ultimate moment } \\
\text { which is obtained } \\
\text { from the moment } \\
\text { curvature relation }\end{array}$ & $\begin{array}{l}\text { i) The reinforcement is } \\
\text { the critical for the } \\
\text { rotation capacity of } \\
\text { the slab, and } \\
\text { ii) The non linear } \\
\text { analysis predicts the } \\
\text { moment curvature for } \\
\text { the position of } \\
\text { negative bending } \\
\text { moment. }\end{array}$ \\
\hline 8 & $\begin{array}{l}\text { Poh and } \\
\text { Atlard }\end{array}$ & $\begin{array}{l}\text { Austral } \\
\text { ia }\end{array}$ & 1992 & Trapezoidal & $\begin{array}{l}\text { Symmet } \\
\text { ric } \\
\text { concent } \\
\text { rated } \\
\text { load }\end{array}$ & $\mathrm{N}$ & $\begin{array}{l}12 \\
\text { samples } \\
\text { tested } \\
\text { by } \\
\text { Abdel- } \\
\text { Sayed et } \\
\text { al. }\end{array}$ & $\begin{array}{l}\text { i) The deflection and } \\
\text { the interface slips } \\
\text { are calculated from } \\
\text { the integration of the } \\
\text { cross sections } \\
\text { curvatures, and } \\
\text { ii)The slab is } \\
\text { considered to fail } \\
\text { when any cross } \\
\text { section along its } \\
\text { length reaches a } \\
\text { maximum value for } \\
\text { moment. }\end{array}$ & $\begin{array}{l}\text { The numerical } \\
\text { presentation was given } \\
\text { to calculate the } \\
\text { interface slip, the } \\
\text { load-deflection and } \\
\text { the strength of the } \\
\text { composite slab under } \\
\text { symmetrical loading. }\end{array}$ \\
\hline 9 & $\begin{array}{l}\text { Daniels } \\
\text { and } \\
\text { Chrisinel }\end{array}$ & $\begin{array}{l}\text { Switzer } \\
\text {-land }\end{array}$ & 1993 & $\begin{array}{l}\text { Rectangular, } \\
\text { Trapezoidal } \\
\text { and } \\
\text { Re-entrant }\end{array}$ & $\begin{array}{l}\text { Concent } \\
\text { rated or } \\
\text { line } \\
\text { loading }\end{array}$ & $\begin{array}{l}\text { A } \\
\& \\
\mathrm{E}\end{array}$ & $\begin{array}{l}\text { 6sample } \\
\text { s (single } \\
\text { span- } \\
\text { type of } \\
\text { decking } \\
\text { )+18 } \\
\text { samples } \\
\text { (spacing } \\
\text { of } \\
\text { loading) } \\
+17 \\
\text { samples } \\
\text { (emboss }\end{array}$ & $\begin{array}{l}\text { The construction, } \\
\text { decking, concreting, } \\
\text { positive moment } \\
\text { reinforcement, slab } \\
\text { length and load } \\
\text { locations are studied }\end{array}$ & $\begin{array}{l}\text { i) The contribution of } \\
\text { each internal moment } \\
\text { resistance element is } \\
\text { non- linear as a } \\
\text { function of the applied } \\
\text { load, and } \\
\text { ii) The concrete slab is } \\
\text { the most important } \\
\text { internal moment } \\
\text { carrying element at } \\
\text { service load levels. }\end{array}$ \\
\hline
\end{tabular}




\begin{tabular}{|c|c|c|c|c|c|c|c|c|c|}
\hline & & & & & & & $\begin{array}{l}\text { ments \& } \\
\text { anchora } \\
\text { ges) }\end{array}$ & & \\
\hline $\begin{array}{l}1 \\
0\end{array}$ & $\begin{array}{l}\text { Andrade, } \\
\text { Vellasco, } \\
\text { Silva and } \\
\text { Takey }\end{array}$ & Brazil & 2004 & $\begin{array}{l}\text { Trapezoidal, } \\
\text { rectangular } \\
\text { and } \\
\text { Reentrant }\end{array}$ & $\begin{array}{l}\text { Static } \\
\text { loading }\end{array}$ & $\begin{array}{l}\mathrm{A} \\
\& \\
\mathrm{E}\end{array}$ & $\begin{array}{l}8 \\
\text { samples }\end{array}$ & $\begin{array}{l}\text { The experiment is } \\
\text { divided into two: } \\
\text { i) Development of a } \\
\text { wide-rib composite } \\
\text { steel deck and } \\
\text { ii) Parametric design } \\
\text { study of the steel } \\
\text { deck profile. }\end{array}$ & $\begin{array}{l}\text { i) Do not require } \\
\text { standard scaffolding } \\
\text { and propping systems } \\
\text { and the intrinsic } \\
\text { construction speed, } \\
\text { ii) High associated } \\
\text { stiffness allowing the } \\
\text { achievement of longer } \\
\text { spans. }\end{array}$ \\
\hline $\begin{array}{l}1 \\
1\end{array}$ & $\begin{array}{l}\text { Abdullah } \\
\text { and } \\
\text { Easterling }\end{array}$ & $\begin{array}{l}\text { Malays } \\
\text { ia }\end{array}$ & 2004 & Trapezoidal & $\begin{array}{l}\text { Static } \\
\text { loading }\end{array}$ & $\begin{array}{l}\text { A } \\
\& \\
\text { E }\end{array}$ & $\begin{array}{l}24 \\
\text { samples }\end{array}$ & 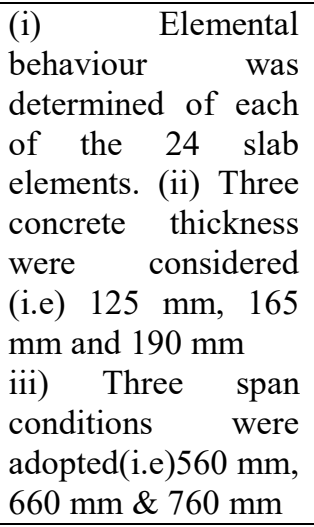 & $\begin{array}{l}\text { i) The elemental tests } \\
\text { were found } \\
\text { comparable with the } \\
\text { full scale testing. } \\
\text { ii) Edge web curling, } \\
\text { end anchorage details, } \\
\text { and type of support } \\
\text { have significant } \\
\text { influence on the slab } \\
\text { specimen strength and } \\
\text { behaviour. }\end{array}$ \\
\hline $\begin{array}{l}1 \\
2\end{array}$ & $\begin{array}{l}\text { Lams and } \\
\text { Qureshi }\end{array}$ & $\begin{array}{l}\text { Singap } \\
\text { ore }\end{array}$ & 2008 & Trapezoidal & $\begin{array}{l}\text { Static } \\
\text { and } \\
\text { cyclic } \\
\text { loading }\end{array}$ & $\mathrm{E}$ & $\begin{array}{l}12 \\
\text { samples }\end{array}$ & $\begin{array}{l}\text { i) Two long } \\
\text { specimens were } \\
\text { used (i.e) } 5.0 \mathrm{~m} \text { and } \\
3.0 \mathrm{~m} \text {. } \\
\text { ii) For the m-k test } \\
\text { two types of loading } \\
\text { were adopted (i.e) } \\
\text { static and cyclic } \\
\text { loading }\end{array}$ & $\begin{array}{l}\text { i) The testing and } \\
\text { evaluation of the slabs } \\
\text { were done in } \\
\text { accordance to the Euro } \\
\text { code } 4 \text {. } \\
\text { ii) Failure in short- } \\
\text { span specimens was } \\
\text { accompanied by } \\
\text { horizontal slip at the } \\
\text { ends, } \\
\text { separation between the } \\
\text { steel and the concrete } \\
\text { and local buckling of } \\
\text { the profiled sheeting } \\
\text { near the supports. }\end{array}$ \\
\hline $\begin{array}{l}1 \\
3\end{array}$ & $\begin{array}{l}\text { Jeong, } \\
\text { Kim and } \\
\text { Koo }\end{array}$ & Korea & 2009 & Trapezoidal & $\begin{array}{l}\text { Static } \\
\text { loading }\end{array}$ & $\mathrm{E}$ & $\begin{array}{l}16 \\
\text { samples } \\
\text { for full } \\
\text { scale } \\
\text { loading } \\
\text { test \& } 6 \\
\text { nos. of } \\
\text { push out } \\
\text { test } \\
\text { sample }\end{array}$ & $\begin{array}{l}\text { The perfobond rib } \\
\text { connector was used } \\
\text { as a shear connector } \\
\text { for which the push } \\
\text { out test was carried } \\
\text { out to determine the } \\
\text { shear bond strength }\end{array}$ & $\begin{array}{l}\text { i) The longitudinal } \\
\text { shear resistances were } \\
\text { analysed using m-k } \\
\text { method } \\
\text { ii) The longitudinal } \\
\text { shear resistances have } \\
\text { led to over estimation. }\end{array}$ \\
\hline $\begin{array}{l}1 \\
4\end{array}$ & $\begin{array}{l}\text { Irwan, } \\
\text { Hanizah } \\
\text { and Azmi }\end{array}$ & $\begin{array}{l}\text { Malays } \\
\text { ia }\end{array}$ & 2009 & Trapezoidal & $\begin{array}{l}\text { Static } \\
\text { loading- } \\
\text { push out } \\
\text { test }\end{array}$ & $\begin{array}{l}\mathrm{A} \\
\& \\
\mathrm{E}\end{array}$ & $\begin{array}{l}68 \\
\text { samples }\end{array}$ & $\begin{array}{l}\text { Bent up shear } \\
\text { transfer } \\
\text { enhancement } \\
\text { mechanism. }\end{array}$ & $\begin{array}{l}\text { BTTST enhancement } \\
\text { is a viable alternative } \\
\text { for a shear } \\
\text { connector } 40 \% \\
\text { increase in concrete }\end{array}$ \\
\hline
\end{tabular}




\begin{tabular}{|c|c|c|c|c|c|c|c|c|c|}
\hline & & & & & & & & & strength. \\
\hline $\begin{array}{l}1 \\
5\end{array}$ & $\begin{array}{l}\text { Chen, Shi } \\
\text { and Qiu }\end{array}$ & China & 2011 & Rectangular & $\begin{array}{l}\text { Static } \\
\text { loading }\end{array}$ & $\begin{array}{l}\mathrm{A} \\
\& \\
\mathrm{E}\end{array}$ & $\begin{array}{l}13 \\
\text { samples }\end{array}$ & $\begin{array}{l}\text { i) The strain gauges } \\
\text { and the LVTDs are } \\
\text { employed to capture } \\
\text { the strain } \\
\text { distribution and } \\
\text { variation. } \\
\text { ii) The longitudinal } \\
\text { shear force deduced } \\
\text { are proportional to } \\
\text { the vertical shear } \\
\text { force in terms of } \\
\text { shear bond strength } \\
\text { in m-k method. }\end{array}$ & $\begin{array}{l}\text { i) The shear bond } \\
\text { failure occurs by crack } \\
\text { in bottom concrete } \\
\text { initiates } \\
\text { ii) The shear bond slip } \\
\text { and separation occurs } \\
\text { by the loss of shear } \\
\text { bond strength. } \\
\text { iii) The longitudinal } \\
\text { shear bond stress } \\
\text { among shear span } \\
\text { contributes to the } \\
\text { longitudinal shear } \\
\text { bond strength }\end{array}$ \\
\hline $\begin{array}{l}1 \\
6\end{array}$ & $\begin{array}{l}\text { Bouchair, } \\
\text { Bujnak, } \\
\text { Duratna } \\
\text { and Lachal }\end{array}$ & France & 2012 & $\begin{array}{l}\text { Conventiona } \\
1 \text { rectangular } \\
\text { slab }\end{array}$ & $\begin{array}{l}\text { Static } \\
\text { loading } \\
\text { (push } \\
\text { out test) }\end{array}$ & $\begin{array}{l}\text { A } \\
\& \\
\text { E }\end{array}$ & $\begin{array}{l}4 \\
\text { samples }\end{array}$ & $\begin{array}{l}\text { The behaviour of } \\
\text { studs was stimulated } \\
\text { by a three- } \\
\text { dimensional quarter } \\
\text { scale finite element } \\
\text { model using } \\
\text { ATENA software. }\end{array}$ & $\begin{array}{l}\text { A finite element } \\
\text { model has been } \\
\text { developed to stimulate } \\
\text { the load slip } \\
\text { characteristics of } \\
\text { headed shear stud in a } \\
\text { solid reinforced } \\
\text { concrete slab }\end{array}$ \\
\hline $\begin{array}{l}1 \\
7\end{array}$ & $\begin{array}{l}\text { Pires, } \\
\text { Rodrigues } \\
\text { and Silva }\end{array}$ & $\begin{array}{l}\text { Portuga } \\
\text { l, } \\
\text { Brazil }\end{array}$ & 2013 & Trapezoidal & $\begin{array}{l}\text { Static } \\
\text { loading }\end{array}$ & $\mathrm{E}$ & & $\begin{array}{l}\text { Restrained thermal } \\
\text { elongation }\end{array}$ & $\begin{array}{lr}\text { Reduction in load } \\
\text { level and slenderness } \\
\text { of columns enhance } \\
\text { performance } \\
\text { columns in fire. }\end{array}$ \\
\hline $\begin{array}{l}1 \\
8\end{array}$ & Gilbert & $\begin{array}{l}\text { Austral } \\
\text { ia }\end{array}$ & 2013 & Trapezoidal & $\begin{array}{l}\text { Sustaine } \\
\mathrm{d} \\
\text { loading }\end{array}$ & A & $\begin{array}{l}10 \\
\text { composi } \\
\text { te } \\
\text { samples } \\
+\quad 12 \\
\text { RCC } \\
\text { slab } \\
\text { samples }\end{array}$ & $\begin{array}{l}\text { The deflections } \\
\text { were calculated on } \\
\text { the basis of long } \\
\text { term sustained } \\
\text { loading over the slab } \\
\text { acting along with its } \\
\text { self weight. }\end{array}$ & $\begin{array}{l}\text { For composite slabs } \\
\text { carrying superimposed } \\
\text { loads typical of the } \\
\text { magnitudes applied to } \\
\text { the floors of most } \\
\text { buildings, } \\
\text { shrinkage deflection is } \\
\text { often more than } 50 \% \\
\text { of the total deflection. }\end{array}$ \\
\hline $\begin{array}{l}1 \\
9\end{array}$ & $\begin{array}{l}\text { Lakshmina } \\
\text { than, } \\
\text { Sivakumar, } \\
\text { Ravichand } \\
\text { ran and } \\
\text { Jeyachandr } \\
\text { an }\end{array}$ & India & 2013 & $\begin{array}{l}\text { Trapezoidal } \\
\text { and } \\
\text { Reentrant }\end{array}$ & $\begin{array}{l}\text { Static } \\
\text { loading }\end{array}$ & $\mathrm{E}$ & $\begin{array}{l}\text { 3sample } \\
\text { (without } \\
\text { shear } \\
\text { connect } \\
\text { ors)+3 } \\
\text { samples } \\
\text { (with } \\
\text { shear } \\
\text { connect } \\
\text { ors)+3 } \\
\text { samples } \\
\text { (with } \\
\text { shear } \\
\text { connect } \\
\text { ors and } \\
\text { continu } \\
\text { ous rods }\end{array}$ & $\begin{array}{l}\text { i)Different } \\
\text { embossment type } \\
\text { shear connector was } \\
\text { used. } \\
\text { ii) Minimum } \\
\text { reinforcement was } \\
\text { provided to avoid } \\
\text { shrinkage }\end{array}$ & $\begin{array}{l}\text { i) The composite slab } \\
\text { without shear } \\
\text { connectors fail early. } \\
\text { ii) The minimum } \\
\text { reinforcements in the } \\
\text { form of mesh were } \\
\text { found to resist } \\
\text { temperature and } \\
\text { shrinkage effects. }\end{array}$ \\
\hline
\end{tabular}




\begin{tabular}{|c|c|c|c|c|c|c|c|c|c|}
\hline $\begin{array}{l}2 \\
0\end{array}$ & $\begin{array}{l}\text { Abdullah, } \\
\text { Bailey and } \\
\text { Wu }\end{array}$ & UK & 2013 & Rectangular & $\begin{array}{l}\text { Cyclic } \\
\text { loading }\end{array}$ & $\mathrm{E}$ & $\begin{array}{l}5 \\
\text { samples }\end{array}$ & $\begin{array}{l}\text { The structural } \\
\text { response of the } \\
\text { strengthened } \\
\text { specimen was } \\
\text { compared with the } \\
\text { non strengthened } \\
\text { specimen in terms of } \\
\text { punching shear } \\
\text { strength, strain and } \\
\text { deflection profile. }\end{array}$ & $\begin{array}{l}\text { The flexural strength } \\
\text { of the composite slab } \\
\text { connections using } \\
\text { FRP increased the } \\
\text { load bearing capacity } \\
\text { by } 43 \% \text { over the non } \\
\text { strengthened slab } \\
\text { specimen }\end{array}$ \\
\hline $\begin{array}{l}2 \\
1\end{array}$ & $\begin{array}{l}\text { A. } \\
\text { Gholamho } \\
\text { sini, } \\
\text { R.I. } \\
\text { Gilbert, } \\
\text { M.A. } \\
\text { Bradford } \\
\text { and } \\
\text { Z.T. Chang }\end{array}$ & $\begin{array}{l}\text { Austral } \\
\text { ia }\end{array}$ & 2014 & $\begin{array}{l}\text { Trapezoidal } \\
\text { and } \\
\text { Reentrant }\end{array}$ & $\begin{array}{l}\text { Static } \\
\text { Line } \\
\text { loading }\end{array}$ & $\mathrm{E}$ & $\begin{array}{l}2 \\
\text { samples } \\
\text { with } \\
\text { trapezoi } \\
\text { dal }+ \\
2 \\
\text { reentran } \\
\text { t } \\
\text { samples }\end{array}$ & $\begin{array}{l}\text { i) Two shear spans } \\
\text { were studied at } \\
\left(\frac{\mathrm{L}}{4} \text { and } \frac{\mathrm{L}}{6}\right) \text { and the end } \\
\text { slips at both the } \\
\text { roller and pin } \\
\text { supports were } \\
\text { recorded. } \\
\text { ii) Two cases were } \\
\text { considered } \\
\text { 1. While there is no } \\
\text { slip } \\
\text { 2. When there is a } \\
\text { partial connection } \\
\text { allowing slip. }\end{array}$ & $\begin{array}{l}\text { The ultimate shear } \\
\text { stress of the slab for } \frac{L}{6} \\
\text { was greater than } \frac{L}{4} \text {. } \\
\text { Then the Finite } \\
\text { element model } \\
\text { utilizing interface } \\
\text { elements to model the } \\
\text { bond properties } \\
\text { between the steel } \\
\text { decking and the } \\
\text { concrete slab was } \\
\text { described and used to } \\
\text { investigate the } \\
\text { behaviour of the slab } \\
\text { throughout the full } \\
\text { range loading. }\end{array}$ \\
\hline $\begin{array}{l}2 \\
2\end{array}$ & $\begin{array}{l}\text { A.Siva, } \\
\text { R.Senthil } \\
\text { and } \\
\text { Saddam M } \\
\text { Ahmed }\end{array}$ & India & 2016 & Trapezoidal & $\begin{array}{l}\text { Static } \\
\text { Line } \\
\text { loading }\end{array}$ & $\mathrm{E}$ & $\begin{array}{l}6 \\
\text { samples } \\
\text { with } \\
\text { trapezoi } \\
\text { dal }\end{array}$ & $\begin{array}{l}\text { Short \& Long shear } \\
\text { span }\end{array}$ & $\begin{array}{l}\text { Experimental } \\
\text { investigations are } \\
\text { needed for each type } \\
\text { of embossed profiled } \\
\text { sheet to verify the 'm' } \\
\text { and ' } k \text { ' values. Short } \\
\text { shear slab with } \\
\text { rectangular } \\
\text { embossments showed } \\
\text { greater shear bond } \\
\text { capacity as compared } \\
\text { to the long shear span } \\
\text { specimens. }\end{array}$ \\
\hline $\begin{array}{l}2 \\
3\end{array}$ & $\begin{array}{l}\text { Swaminath } \\
\text { an.S, A. } \\
\text { Siva, R. } \\
\text { Senthil and } \\
\text { Kinson } \\
\text { Prabu }\end{array}$ & India & 2016 & Trapezoidal & $\begin{array}{l}\text { Static } \\
\text { Line } \\
\text { loading }\end{array}$ & $\mathrm{E}$ & $\begin{array}{l}6 \\
\text { samples } \\
\text { with } \\
\text { trapezoi } \\
\text { dal }\end{array}$ & $\begin{array}{lr}\text { Bolted } & \text { shear } \\
\text { connector, } & \text { Headed } \\
\text { stud shear connector }\end{array}$ & $\begin{array}{l}\text { Three major types of } \\
\text { failure were detected. } \\
\text { The first failure is } \\
\text { crushing of concrete } \\
\text { and shear, second type } \\
\text { of failure is buckling } \\
\text { of shear stud } \\
\text { connector and } \\
\text { combining of both } \\
\text { shear connector and } \\
\text { concrete is third type } \\
\text { of failure. }\end{array}$ \\
\hline $\begin{array}{l}2 \\
4\end{array}$ & $\begin{array}{l}\text { A.Siva, } \\
\text { S.Swamina } \\
\text { than, } \\
\text { K.Prasanth } \\
\text { \&R.Senthil }\end{array}$ & $\begin{array}{l}\text { Switzer } \\
\text { land }\end{array}$ & 2016 & Trapezoidal & $\begin{array}{l}\text { Static } \\
\text { Line } \\
\text { loading }\end{array}$ & $\mathrm{E}$ & $\begin{array}{l}6 \\
\text { samples } \\
\text { with } \\
\text { trapezoi } \\
\text { dal }\end{array}$ & $\begin{array}{l}\text { Varying } \\
\text { Spans }\end{array}$ & $\begin{array}{l}\text { Depending upon the } \\
\text { loading given at } \\
\text { various shear spans } \\
\text { the behavior of the } \\
\text { composite slab varies } \\
\text { accordingly }\end{array}$ \\
\hline
\end{tabular}




\begin{tabular}{|c|c|c|c|c|c|c|c|c|c|}
\hline $\begin{array}{l}2 \\
5\end{array}$ & $\begin{array}{l}\text { A.Siva, } \\
\text { R.Senthil } \\
\text { and } \\
\text { S.Swamina } \\
\text { than }\end{array}$ & $\begin{array}{l}\text { Morocc } \\
\text { o }\end{array}$ & 2016 & Trapezoidal & $\begin{array}{l}\text { Static } \\
\text { Line } \\
\text { loading }\end{array}$ & $\mathrm{E}$ & $\begin{array}{l}6 \\
\text { samples } \\
\text { with } \\
\text { trapezoi } \\
\text { dal }\end{array}$ & $\begin{array}{l}\text { Varies embossments } \\
\text { and Varying Shear } \\
\text { Spans }\end{array}$ & $\begin{array}{l}\text { The longitudinal shear } \\
\text { capacity of the } \\
\text { specimen can be } \\
\text { increased by depth of } \\
\text { the embossment and } \\
\text { orientation of the } \\
\text { embossment. }\end{array}$ \\
\hline
\end{tabular}

*N, E and A are Numerical Investigation, Experimental Investigation and Analytical Investigation respectively. 